\title{
THE AMENDED GUN-FREE SCHOOL ZONES ACT: DOUBT AS TO ITS CONSTITUTIONALITY REMAINS
}

\begin{abstract}
SETH J. SAFRA
The judicial decision making contemplated by the Constitution ... unlike at least the politics of the moment, emphatically is not a function of labels. If it were, the Supreme Court assuredly would not have struck down the "Gun-Free School Zones Act," the "Religious Freedom Restoration Act," the "Civil Rights Act of 1871," or the "Civil Rights Act of 1875." And if it ever becomes such, we will have ceased to be a society of law, and all the codification of freedom in the world will be to little avail. ${ }^{1}$
\end{abstract}

In United States v. Lopez, ${ }^{2}$ the Supreme Court declared the GunFree School Zones Act of 1990 (GFSZA) an unconstitutional exercise of Congress's Commerce Clause power. ${ }^{3}$ The repudiated statute made it a federal offense "for any individual knowingly to possess a firearm at a place that the individual knows, or has reasonable cause to believe, is a school zone." "4

The Court offered several reasons why the ban on possession of firearms in school zones was unconstitutional. First, the Court noted that possession of firearms is not an activity traditionally associated with the federal power over interstate commerce. ${ }^{5}$ Regardless of this

Copyright (c) 2000 by Seth J. Safra

1. Brzonkala v. Virginia Polytechnic Inst. \& State Univ., 169 F.3d 820, 889 (4th Cir. 1999) (reflecting on the political consequences of invalidating a provision in the Violence Against Women Act), aff'd sub nom. United States v. Morrison, 120 S. Ct. 1740 (2000).

2. 514 U.S. 549 (1995).

3. Id. at 552 .

4. Id. at 551 (quoting 18 U.S.C. $\$ 922(\mathrm{q})(1)(\mathrm{A})$ (1988 \& Supp. V)).

5. The majority opinion emphasized that possession of firearms is not an economic activity. See id. at 560-61. Justice Kennedy's concurring opinion, in which Justice O'Connor joined, asserted that GFSZA was problematic because it intruded into areas traditionally left to the states. See id. at 580-83 (Kennedy, J., concurring) ("[I]t is well established that education is a traditional concern of the States."). Of course, if the statute's constitutionality is contingent on 
fundamental problem, the statute could not be upheld because there was no rational basis for concluding that possession of firearms in a school zone affected interstate commerce and there was no "jurisdictional element" to ensure that in each case the possession affected interstate commerce. ${ }^{6}$ Ultimately, the statute was unconstitutional because it was not an exercise of any of the three broad categories of Congress's Commerce Clause power: (1) power over the use of the channels of interstate commerce; (2) power over the instrumentalities of interstate commerce, or things in interstate commerce; and (3) power over activities substantially affecting interstate commerce.

In response to Lopez, Attorney General Janet Reno recommended amendments to GFSZA. These amendments were intended to solve the problems identified in the opinion. ${ }^{8}$ Per General Reno's suggestion, Congress changed the gravamen of the offense from possessing a firearm in a school zone to possessing a firearm "that has moved in or that otherwise affects interstate or foreign commerce" in a school zone. "The added language is a jurisdictional element that limits the statute's "reach to a discrete set of firearm possessions that additionally have an explicit connection with or effect on interstate commerce." ${ }^{10}$ In addition, the new statute includes

how "economic" possessing a firearm is or on tradition, solving the problem of the statute's constitutionality through a legislative fix would be impossible.

6. See id. at 562-63. As its name implies, a "jurisdictional element" is an element of the offense inserted in order to bring the offense within Congress's federal power. See, e.g., United States v. Krilich, 209 F.3d 968, 972 (7th Cir. 2000) ("[T]he nexus with interstate commerce, which courts frequently call the 'jurisdictional element'... is 'jurisdictional' only in the shorthand sense that without that nexus, there can be no federal crime ....") (citation omitted). Like any other element of the offense, the prosecution must prove that the conditions in the "jurisdictional element" existed at the time of the offense. See id. at 531 ("[T]he "jurisdictional element[]' is simply one of the essential elements of [the offense].").

7. See Lopez, 514 U.S. at 558-59 (citations omitted).

8. See Message to Congress Transmitting Proposed Legislation to Amend the Gun-Free School Zones Act of 1990, 1995 PUB. PAPERS 678 (May 10, 1995) [hereinafter Message to Congress].

9. 18 U.S.C. $§ 922(q)(2)(A)$ (Supp. IV 1998) (emphasis added). As the amendments were concealed within the Omnibus Consolidated Appropriations Act of 1997, Pub. L. No. 104-208, $\S 657,110$ Stat. 3009, 3009-369-71 (1996) — an act having nothing to do with safety in schools or guns-they have been widely ignored.

10. Message to Congress, supra note 8 , at 678 . The addition responds to the criticism in Lopez that "\$ 922(q) contains no jurisdictional element which would ensure, through case-bycase inquiry, that the firearm possession in question affects interstate commerce." Lopez, 514 U.S. at 561. The jurisdictional element in this case can be described more accurately as two alternative jurisdictional elements: (1) past movement in interstate commerce, and (2) other effect on interstate commerce. 


\section{legislative findings that possession of guns near schools affects} interstate commerce. ${ }^{11}$

While, on the surface, the changes specifically answer the problems addressed in Lopez, the criminal act remains the samepossession of a gun in a school zone. In fact, when President Clinton proposed the amendments to Congress, he emphasized that the modifications had little or no effect on the ability to prosecute the offense. ${ }^{12}$ Accordingly, the concerns regarding Congress's intrusion into an area traditionally regulated by states and the potential for using the commerce power as a general police power remain. ${ }^{13}$

11. See 18 U.S.C. $\$ 922(q)(1)$ (Supp. IV 1998). The findings were originally added between the time when Mr. Lopez was prosecuted and the time when the Supreme Court issued its opinion. See id.; Lopez, 514 U.S. at 618 (Breyer, J., dissenting) (noting that Congress made findings after Lopez was prosecuted). The findings are enumerated in subparagraphs A through I:

(A) crime, particularly crime involving drugs and guns, is a pervasive, nationwide problem;

(B) crime at the local level is exacerbated by the interstate movement of drugs, guns, and criminal gangs;

(C) firearms and ammunition move easily in interstate commerce and have been found in increasing numbers in and around schools, as documented in numerous hearings in both the Committee on the Judiciary the House of Representatives and the Committee on the Judiciary of the Senate;

(D) in fact, even before the sale of a firearm, the gun, its component parts, ammunition, and the raw materials from which they are made have considerably moved in interstate commerce;

(E) while criminals freely move from State to State, ordinary citizens and foreign visitors may fear to travel to or through certain parts of the country due to concern about violent crime and gun violence, and parents may decline to send their children to school for the same reason;

(F) the occurrence of violent crime in school zones has resulted in a decline in the quality of education in our country;

(G) this decline in the quality of education has an adverse impact on interstate commerce and the foreign commerce of the United States;

(H) States, localities, and school systems find it almost impossible to handle gun-related crime by themselves - even States, localities, and school systems that have made strong efforts to prevent, detect, and punish gun-related crime find their efforts unavailing due in part to the failure or inability of other States or localities to take strong measures; and

(I) the Congress has the power, under the interstate commerce clause and other provisions of the Constitution, to enact measures to ensure the integrity and safety of the Nation's schools by enactment of this subsection.

18 U.S.C. § 922(q)(1) (Supp. IV 1998).

12. See Message to Congress, supra note 8, at 678. Moreover, to be convicted, a defendant must "know only that he or she possesses the firearm" and not that the firearm ever moved in interstate commerce. Id.

13. See supra note 5. To the extent that the Gun-Free School Zones Act was unconstitutional because it "intrude[d] upon an area of traditional state concern," Lopez, 514 U.S. at 580 (Kennedy, J., concurring), and the activity was non-economic, see id. at 560-61, the 
This Note investigates the constitutionality of the amended GunFree School Zones Act. While the end of prohibiting guns near schools is laudable, Congress's power to achieve this end through federal law is in doubt when the only connection to interstate commerce is that the gun previously moved in interstate commerce.

Notwithstanding the problem of regulating a noneconomic activity that is traditionally within the states' authority, the revised Act could only be constitutional if it fits into one of the three categories of Congress's commerce power. Part I investigates whether the jurisdictional element brings the statute within one of the three categories. Part II asks whether adding congressional findings to the statute brings it within one of the three categories. ${ }^{14}$ This Note concludes that, because neither the jurisdictional element nor the congressional findings logically give Congress the requisite power that was lacking in Lopez, grave doubt exists as to the constitutionality of applying the statute where the only nexus to interstate commerce is the firearm's previous movement therein. ${ }^{15}$

legislative fix cannot remedy the problem. The analysis in this Note assumes that, notwithstanding the nature of the offense, an act of Congress that fits within one of the three categories of its Commerce Clause power is constitutional.

14. See supra note 7 and accompanying text.

15. The statute should not be challenged on its face. A facial challenge to the constitutionality of a congressional act-considered "the most difficult challenge to mount successfully"- does not arise unless "no set of circumstances exists under which the Act would be valid." United States v. Salerno, 481 U.S. 739, 745 (1987). In this case, however, there are circumstances under which the Gun-Free School Zones Act could be valid. For example, a person transporting a gun in interstate commerce could pass through a school zone. Regulating possession in that case might be a constitutional exercise of Congress's power over the channels of interstate commerce or Congress's power over things in interstate commerce. See discussion infra Part I.B-C. Similarly, if, in the particular case, an effect on interstate commerce is demonstrated, the act would be valid. See infra note 18 and accompanying text.

The only significant exceptions to the Salerno rule are the doctrines of overbreadth and vagueness. See City of Chicago v. Morales, 527 U.S. 41, 52 (1999) (Stevens, J., plurality opinion). The overbreadth doctrine applies only when there is a substantial infringement, in relation to the statute's "legitimate sweep," upon First Amendment rights. Id. (quoting Broadrick v. Oklahoma, 413 U.S. 601, 615 (1973)). Clearly, First Amendment rights are not at issue in this case. The vagueness doctrine applies when a statute fails to provide adequate notice of the prohibited conduct or encourages arbitrary and discriminatory enforcement. See id. (citing Kolender v. Lawson, 461 U.S. 352, 357 (1983)). For example, a statute that prohibits "remaining in one place "with no apparent purpose"" is vague. Id. at 53. The Gun-Free School Zones Act is not such a statute; the proscribed conduct in this case-possessing a firearm in a school zone-is objectively clear. 


\section{JURISDICTIONAL ELEMENT}

The most significant change to the Gun-Free School Zones Act was the addition of the jurisdictional element, which was intended to ensure that in each case, there is an inquiry as to whether the particular offense falls within Congress's commerce power. ${ }^{16}$ While the requirement that the particular possession affect interstate commerce $^{17}$ makes the statute constitutional on its face, ${ }^{18}$ the statute's constitutionality is doubtful as applied to the case where the only connection to interstate commerce is that the gun "has moved in ... interstate... commerce." ${ }^{\text {"19 }}$ The key issue is whether past movement in interstate or foreign commerce (for example, twenty years before the person possessing the firearm in a school zone obtained it), without more, brings regulation of possession within Congress's power over activities that substantially affect interstate commerce, its power over the channels of interstate commerce, or its power over instrumentalities of interstate commerce and things in interstate commerce. $^{20}$

16. See supra notes $8-10$ and accompanying text.

17. See 18 U.S.C. $\$ 922(q)(2)(A)$ (Supp. IV 1998).

18. Theoretically, one could quibble that because Congress's power reaches only activities that substantially affect interstate commerce, the statute's requirement that the act of possession merely affect interstate commerce is insufficient to make it constitutional. However, such an argument seems to elevate form over substance. Based on Wickard v. Filburn, 317 U.S. 111 (1942), an action with a de minimis effect on interstate commerce is deemed to have a substantial effect on interstate commerce if the aggregate effect from everyone doing it would have a substantial effect on interstate commerce. $I d$. at 128-29. It is hard to imagine how an activity that affects interstate commerce a little bit when performed by one person would not substantially affect interstate commerce when performed by many people.

Past movement in interstate commerce has been termed a "de minimis nexus" to interstate commerce. See, e.g., Antony Barone Kolenc, Commerce Clause Challenges After United States v. Lopez, 50 FLA. L. REV. 867, 878-79 (1998) (referring to the use of a "de minimis nexus" in Scarborough v. United States, 431 U.S. 563, 564 (1977)). This term should not be confused with activities having a de minimis effect on interstate commerce. See supra note 11. Although past movement in interstate commerce might be a de minimis nexus to interstate commerce, the impact of possession on interstate commerce remains nil. Accordingly, movement in interstate commerce should not give subsequent possession even a de minimis effect on interstate commerce.

19. 18 U.S.C. $\$ 922(\mathrm{q})(2)(\mathrm{A})$

20. See supra note 7 and accompanying text. At least one judge has recognized that adding a jurisdictional element to a statute does not end the analysis of whether the statute is constitutional as applied. See Brzonkala v. Virginia Polytechnic Inst. \& State Univ., 169 F.3d 820, 903 n.4 (4th Cir. 1999) (Niemeyer, J., concurring) (noting that its analysis of a statute with no jurisdictional element "does not present the issue of how far Congress can extend its power, if at all, to enact legislation through the use of jurisdictional hooks"), aff'd sub nom. United States v. Morrison, 120 S. Ct. 1740 (2000). 
Section I.A investigates whether the jurisdictional element makes the statute an exercise of Congress's power over activities substantially affecting interstate commerce. Section I.B addresses possible arguments that the jurisdictional element makes the Act an exercise of Congress's power over the channels of interstate commerce, or over instrumentalities of interstate commerce and things in interstate commerce. Although past movement in interstate commerce provides a connection to interstate commerce, there is no basis in constitutional law for the conclusion that such a connection brings the statute within one of those three categories of Congress's power.

\section{A. Activities That Substantially Affect Interstate Commerce}

Although the requirement that the act of possession affect interstate commerce makes the statute facially constitutional, ${ }^{21}$ it is doubtful that past movement in interstate commerce alone is enough to "ensure, through case-by-case inquiry, that the firearm possession in question affects interstate commerce." ${ }^{22}$ As explained below, there is no basis in constitutional law for such a conclusion. ${ }^{23}$

21. See supra note 18 (discussing the missing word "substantially").

22. United States v. Lopez, 514 U.S. 549, 561 (1995) (emphasis added). Without clear authority, it seems to have been assumed that if an item has moved in interstate commerce in the past, it comes within Congress's power. For example, the Sixth Circuit has written, "Lopez... did not disturb the Supreme Court's precedents which indicate that a firearm that has been transported at any time in interstate commerce has a sufficient effect on commerce to allow Congress to regulate the possession of that firearm pursuant to its Commerce Clause powers." United States v. Chesney, 86 F.3d 564, 570-71 (6th Cir. 1996); see also Message to Congress, supra note 8, at 678 (assuming that limiting the statute's reach to firearms that have moved in interstate commerce would bring it within Congress's Commerce Clause authority); Donald H. Regan, How to Think About the Federal Commerce Power and Incidentally Rewrite United States v. Lopez, 94 MICH. L. REV. 554, 567-68 (1995) (concluding almost summarily that regulating possession of a firearm that has moved in interstate commerce would be constitutional). Even Justice Breyer has noted Congress's ability to derive power by relating regulations to movement in interstate commerce. See United States v. Morrison, 120 S. Ct. 1740, 1776 (2000) (Breyer, J., concurring) ("[I]n a world where most everyday products or their component parts cross interstate boundaries, Congress will frequently find it possible to redraft a statute using language that ties the regulation to the interstate movement of some relevant object...."). Disturbed by how illogical it would be to draw the line between what is constitutional and what is not with an irrelevant hook, Justice Breyer sarcastically quipped that Congress should amend the recently repudiated Violence Against Women Act to forbid " "Violence Against Women ... by Those Who Have Moved in, or through the Use of Items that Have Moved in, Interstate Commerce." Id. (Of course, Justice Breyer's argument suggested the alternative solution to resolving the conundrum-uphold the statute even though it contains no jurisdictional element.)

23. See infra notes 39-64 and accompanying text. 
Congress's power over activities that substantially affect interstate commerce has been succinctly stated: "[i]f it is interstate commerce that feels the pinch, it does not matter how local the operation which applies the squeeze." "24 To assure that Congress regulated only activities whose squeeze was felt by interstate commerce, early-twentieth-century Commerce Clause jurisprudence limited Congress's powers to activities with a direct impact on interstate commerce. ${ }^{25}$ Eventually, whether a pinch on interstate commerce was sufficient to justify federal regulation became a question of degree, much like proximate cause in tort. $^{26}$ In application, the modern test has shifted from whether there is a direct impact on interstate commerce to whether Congress rationally could have believed that the activity affects interstate commerce. ${ }^{27}$

24. Heart of Atlanta Motel, Inc. v. United States, 379 U.S. 241, 258 (1964) (quoting United States v. Women's Sportswear Mfg. Ass'n, 336 U.S. 460, 464 (1949)).

25. See, e.g., A.L.A. Schechter Poultry Corp. v. United States, 295 U.S. 495, 546 (1935) (noting that Congress's power is limited to transactions that directly affect interstate commerce and hypothesizing that if the commerce power reached all activities with an indirect effect on interstate commerce, "even the development of the State's commercial facilities would be subject to federal control").

26. See NLRB v. Jones \& Laughlin Steel Corp., 301 U.S. 1, 37 (1937) (describing the boundary of Congress's power as a question of degree, bounded by activities with "effects upon interstate commerce so indirect and remote that to embrace them, in view of our complex society, would effectually obliterate the distinction between what is national and what is local and create a completely centralized government"). Perhaps the question of degree is best illustrated by the metaphor in Justice Cardozo's concurring opinion in Schechter Poultry, two years before the approach was adopted by a majority of the Court:

Motion at the outer rim is communicated perceptibly, though minutely, to recording

instruments at the center.... Activities local in their immediacy do not become interstate and national because of distant repercussions. What is near and what is distant may at times be uncertain.

Schechter Poultry, 295 U.S. at 554 (Cardozo, J., concurring).

27. See, e.g., Heart of Atlanta Motel, 379 U.S. at 258. Although the Court's recent opinion in Morrison recognized that the modern commerce power is much broader than it was historically, see United States v. Morrison, 120 S. Ct. 1740, 1748 (2000) ("Congress has had considerably greater latitude in regulating conduct and transactions under the Commerce Clause than our previous case law permitted."), language in that opinion could in fact narrow Congress's power. Citing cases that stood for the proposition that the Court is the ultimate arbiter of whether Congress could have had a rational basis for concluding that an activity substantially affected interstate commerce, the Court asserted that "“[w]hether particular operations affect interstate commerce sufficiently to come under the constitutional power of Congress to regulate them is ultimately a judicial rather than a legislative question, and can be settled finally only by this Court." Id. at 1752 (emphasis added) (quoting Lopez, 514 U.S. at 557 $\mathrm{n} .2$ ). Although it remains to be seen how this language will be applied, this assertion could limit the deference traditionally given to Congress's determination of the extent of its power. Compare id. with JOHN E. NOWAK \& RONALD D. ROTUNDA, CONSTITUTIONAL LAW § 4.8, at 154 (4th ed. 1991) ("The Court [before Lopez] now will defer to the legislature's choice of 
For example, because Congress rationally could have believed that local discrimination in hotels and restaurants substantially affects interstate commerce, the Supreme Court has upheld legislation prohibiting such discrimination. ${ }^{28}$ Similarly, Congress successfully regulated the manufacturing of goods before they enter into the stream of interstate commerce. ${ }^{29}$ Although the precise limit of this power is unclear, "even under our modern, expansive interpretation of the Commerce Clause, Congress' regulatory authority is not without effective bounds." ${ }^{30}$ To be sure, Congress does not have the power to make it a federal offense "'for any individual knowingly to possess a firearm at a place that the individual knows, or has reasonable cause to believe, is a school zone." ${ }^{31}$ Possession of a firearm in a school zone, without more, does not substantially affect interstate commerce. ${ }^{32}$

This line leads one to question how, if possession of a firearm in a school zone does not substantially affect interstate commerce, possession of a "special" firearm-one that previously moved in interstate commerce-could substantially affect interstate commerce. The logical response is that previous movement in interstate commerce has nothing to do with whether a particular act of possession affects interstate commerce; the item's history, therefore, should not affect the statute's constitutionality. ${ }^{33}$ Nevertheless, courts have distinguished Lopez precisely on that basis.

economic rationale ... The justices will defer to the legislative choices in this area and uphold laws if there is a rational basis upon which Congress could find a relation between its regulation and commerce.").

28. See Katzenbach v. McClung, 379 U.S. 294, 303-04 (1964) (upholding a federal ban on discrimination in an intrastate restaurant that received a substantial amount of its food in interstate commerce, because the restaurant sold less food as a result of the discrimination, thereby affecting the quantity of food moving in interstate commerce); Heart of Atlanta Motel, 379 U.S. at 252-53 (holding that Congress could ban discrimination in a hotel because such discrimination hinders interstate travel of African Americans, thereby interrupting interstate commerce).

29. See United States v. Darby, 312 U.S. 100, 117-20 (1941) (upholding federal wage and hour requirements on the basis that employees' labor conditions substantially affect interstate commerce).

30. Morrison, 120 S. Ct. at 1748 (citing Lopez, 514 U.S. at 557).

31. Lopez, 514 U.S. at 551 (quoting 18 U.S.C. § 922(q)(1)(A) (Supp. V 1988)).

32. See id. at 562 (noting that a substantial effect on interstate commerce was not plainly visible and that there were no findings within the statute or legislative history demonstrating the effects of possessing a gun in a school zone on interstate commerce).

33. See Steven D. Clymer, Unequal Justice: The Federalization Of Criminal Law, $70 \mathrm{~S}$. CAL. L. REV. 643, 667 (1997) (noting that Lopez might change the existing doctrine by "precluding the federal government from using proof of a minimal effect on interstate commerce [past 
Since 1995, statutes such as 18 U.S.C. $\S 922(\mathrm{~g})$ - which makes it a crime for convicted felons to "possess in or affecting commerce, any firearm or ammunition; or to receive any firearm or ammunition which has been shipped or transported in interstate or foreign commerce" ${ }^{\prime 34}$ - have withstood constitutional challenges due to the presence of a jurisdictional element. ${ }^{35}$ While there is little argument that the jurisdictional element makes the statute constitutional on its face, ${ }^{36}$ courts have used the language to perform a constitutional sleight of hand, declaring that "affecting interstate commerce" can be "satisfied if the illegally possessed firearm had previously traveled in interstate commerce." 37 Such a conclusion amounts to the ultimate triumph of form over substance. ${ }^{38}$

The conclusion that "in or affecting commerce" are "jurisdictional words of art" " requiring only a showing that the firearm previously traveled in interstate commerce ${ }^{40}$ is based on the Supreme Court's opinions in United States v. Bass ${ }^{41}$ and Scarborough

movement] as a jurisdictional hook to support federal prosecution"); Eric Grossman, Comment, Where Do We Go From Here? The Aftermath and Application of United States v. Lopez, 33 Hous. L. REV. 795, 799 (1996) (questioning whether "Congress [is] really regulating 'interstate commerce' simply because an object happened to travel in interstate commerce six months, five years, or thirty years ago" and noting that this finding alone is being used by lower courts to distinguish Lopez).

34. 18 U.S.C. $\$ 922(\mathrm{~g})$ (1994) (emphasis added).

35. See, e.g., United States v. Pierson, 139 F.3d 501, 503 (5th Cir. 1998) (distinguishing 18 U.S.C. $\$ 922(\mathrm{~g})$ from the statute repudiated in Lopez because it had the element the absence of which was "[c]entral to the Lopez court's holding"-a jurisdictional element reaching only possession that affects commerce).

36. See supra note 18.

37. Pierson, 139 F.3d at 503-04 (citing United States v. Rawls, 85 F.3d 240, 242 (5th Cir. 1996)); see also United States v. Wells, 98 F.3d 808, 811 (4th Cir. 1996) (citing Scarborough v. United States, 431 U.S. 563, 575 (1977)).

38. Cf. United States v. Bishop, 66 F.3d 569, 596 (3d Cir.) (Becker, J., dissenting) (conceiving that jurisdictional words of art "would permit a federal law outlawing the theft of a Hershey kiss from a corner store in Youngstown, Ohio by a neighborhood juvenile on the basis that the candy once traveled in interstate commerce to the store from Hershey, Pennsylvania"), cert. denied, 516 U.S. 1032 (1995), and cert. denied sub nom. Stokes v. United States, 516 U.S. 1066 (1996); Carlo D'Angelo, The Impact of United States v. Lopez upon Selected Firearms Provisions of Title 18 U.S.C. $\$ 922,8$ ST. THOMAS L. REV. 571, 583-84 (1996) (questioning the authority of Scarborough in light of Lopez on the basis that virtually everything has "at one time or another seen the borders of a foreign state").

39. United States v. Gillies, 851 F.2d 492, 493 (1st Cir. 1988).

40. See Wells, 98 F.3d at 811 (asserting that "in or affecting commerce" requires a minimal nexus to interstate commerce); see also Pierson, 139 F.3d at 503-04 (asserting that the minimal nexus required is a showing that the firearm previously traveled in interstate commerce).

41. 404 U.S. 336 (1971). 
v. United States. ${ }^{42}$ Although courts and scholars have treated the opinions as constitutional law, ${ }^{43}$ the cases never settled the constitutional issue.

In Bass, the Supreme Court interpreted a statute prohibiting a convicted felon from "receiv[ing], possess[ing], or transport[ing] in commerce or affecting commerce... any firearm." Court was asked whether "in commerce or affecting commerce" applied to "receive" and "possess" or whether it applied only to "transport." "45 Because ambiguity of criminal statutes "should be resolved in favor of lenity," jurisdictional element applied to "possess."

42. 431 U.S. 563 (1977).

43. See, e.g., Pierson, 139 F.3d at 503-04 (citing, albeit indirectly, Scarborough, 431 U.S. at 575 , for the proposition that "the 'in or affecting' commerce element can be satisfied if the illegally possessed firearm had previously traveled in interstate commerce"); Wells, 98 F.3d at 811 (citing Scarborough, 431 U.S. at 575, for the proposition that "the existence of [a] jurisdictional element... distinguishes Lopez and satisfies the minimal nexus required for the Commerce Clause"); Harry Litman \& Mark D. Greenberg, Federal Power and Federalism: A Theory of Commerce-Clause Based Regulation of Traditionally State Crimes, 47 CASE W. RES. L. REV. 921, 932 (1997) (referring to Scarborough's "necessar[y], if implicit[]," holding that regulating guns that have moved in interstate commerce is within Congress's constitutional power); supra note 22.

44. Bass, 404 U.S. at 337 (quoting 18 U.S.C.A. $§ 1202$ (a) (1968)) (emphasis added). Section 1202(a) was the predecessor to section $922(\mathrm{~g})$. The relevant parts of this statute are now found in 18 U.S.C. $\S 922(\mathrm{~g})(1994)$.

45. See id. at 338. Mr. Bass argued in the alternative that if "in commerce or affecting commerce" applied only to transport, the statute was not within Congress's constitutional power. See id. Because the Court held that "in commerce or affecting commerce" also applied to "receive" and "possess," the Court never reached the question of whether the statute could be constitutional if it prohibited receipt and possession without the "in commerce or affecting commerce" limitation. See id. at 338-39.

46. Id. at 347 (quoting Rewis v. United States, 401 U.S. 808, 812 (1971)).

47. See id. at 347. The Court also mentioned a desire to protect the federal-state balance. See id. at 349 (asserting that a statute will not be interpreted "to have significantly changed the federal-state balance" unless Congress conveys a clear purpose to do so). Reaching possession that did not affect interstate commerce would have broadened Congress's power significantly. The Court reasoned that if such broad power was Congress's intent, Congress would have made such an intent more clear. See id.

Although recent decisions might make the traditional federal-state balance part of the constitutional analysis, see, e.g., United States v. Lopez, 514 U.S. 549, 577 (1995) (Kennedy, J., concurring) ("Were the Federal Government to take over the regulation of entire areas of traditional state concern, areas having nothing to do with the regulation of commercial activities, the boundaries between the spheres of federal and state authority would blur and political responsibility would become illusory."); Brzonkala v. Virginia Polytechnic Inst. \& State Univ., 169 F.3d 820, 903 (4th Cir. 1999) (Niemeyer, J., concurring) (considering whether a statute "unduly intrudes on the general police power retained by the States"), aff'd sub. nom. United States v. Morrison, 120 S. Ct. 1740 (2000), the focus on federal-state balance in Bass is 
based on the constitutional limits of Congress's commerce power. Indeed, because the government never attempted to prove the "in commerce or affecting commerce" element of possession, ${ }^{48}$ the Court never had an opportunity to opine whether past movement in interstate commerce would meet the minimum threshold for satisfying the jurisdictional element.

Although Bass did not establish a minimum threshold for satisfying "in commerce or affecting commerce," the Court suggested in dictum what possession "in commerce or affecting commerce" might have meant. ${ }^{49}$ Possession "in commerce" referred to possession while the item was moving in interstate commerce or located within an interstate facility. ${ }^{50}$ Possession "affecting commerce" required a showing of how the possession affected commerce. ${ }^{51}$ The opinion did not suggest how one might show that possession affected commerce. ${ }^{52}$ Thus, there was no suggestion that past movement in interstate commerce brought possession within Congress's power over activities that substantially affect commerce.

The meaning of "in commerce or affecting commerce" was revisited in Scarborough..$^{53}$ Although the Court held that previous movement in interstate commerce satisfied the statutory requirement of "in commerce or affecting commerce," the Court did not address the question of whether past movement satisfied the constitutional requirement. $^{54}$ The Scarborough holding was based on legislative history, not upon constitutional law. ${ }^{55}$ The record indicated that Congress intended to outlaw all possession of weapons by convicted felons. ${ }^{56}$ In this regard, the legislative history included findings that

purely prudential.

48. Bass, 404 U.S. at 338-39 (noting that the government assumed that the statute banned possession of firearms by convicted felons regardless of whether there was a connection to interstate commerce).

49. See id. at $350-51$.

50. See id. at 350 .

51. See id.

52. See id. at 350-51. Bass never asserted that mere possession of an item that moved in interstate commerce would satisfy the requirement. See id.

53. Scarborough v. United States, 431 U.S. 563, $567-71$ (1977)

54. See id. at 575.

55. Like most exercises in statutory construction, the Scarborough Court started by attempting to interpret the statutory language. However, because the Court found "in or affecting commerce" to be ambiguous, it examined the legislative history. See id. (discussing the language of the statute and shifting to the rationale for its insertion).

56. See id. at 572-73 (quoting Senator Long's statement, 114 CONG. REC. 14,773-74 (1968), that the amendment " would deny every assassin, murderer, thief and burglar of [sic] the right to 
possession of firearms by felons was "a burden on commerce or threat affecting the free flow of commerce. ${ }^{, 57}$ Because Congress was not sure whether its findings were sufficient to give it power over all possession, ${ }^{58}$ Congress added the restriction that the possession had to be "in commerce or affecting commerce." ${ }^{, 9}$ As Congress's ultimate intent was to reach all possession, the Court was able to conclude that Congress intended "or affecting commerce" to be satisfied when the gun had moved in interstate commerce.$^{60}$ While the Court articulated Congress's intended meaning of the language, it did not address the question of whether Congress's intended meaning was constitutional.

Although the Court generally avoids constitutionally doubtful statutory constructions, ${ }^{61}$ Scarborough's statutory construction should not be relied upon as constitutional precedent. Scarborough was written eighteen years before Lopez. At that time, the Commerce Clause had not been used to limit Congress's power in forty years. ${ }^{62}$ Because the parties never raised the question of constitutionality, the Court had no reason to consider the issue. It was simply assumed either that possession of firearms always affects interstate commerce or that past movement in interstate commerce made possession of the firearm affect interstate commerce. ${ }^{63}$ From the line drawn by Lopez

possess a firearm in the future"') (emphasis added).

57. Id. at $571 \mathrm{n} .10$ (quoting 18 U.S.C. $\$ 1201(1)$ ).

58. See id. at 575 ("It seems apparent... that the purpose of Title VII was to proscribe mere possession but that there was some concern about the constitutionality of such a statute.").

59. Id. at 567.

60. See id.

61. See DeBartolo Corp. v. Florida Gulf Coast Bldg. \& Constr. Trades Council, 485 U.S. 568,575 (1988) (“[W]here an otherwise acceptable construction of a statute would raise serious constitutional problems, the Court will construe the statute to avoid such problems unless such construction is plainly contrary to the intent of Congress.").

62. During the period beginning with NLRB v. Jones \& Laughlin Steel Corp. and ending with Lopez, every Commerce Clause challenge to a regulation of private sector commercial activity failed. See NOWAK \& RoTUNDA, supra note 27, § 4.9, at 160 ("The Court since 1938 has not restricted the scope of federal power to regulate private sector commercial activity even though the regulation might seem to be local in nature."); LAURENCE H. TRIBE, AMERICAN CONSTITUTIONAL LAW, $§ 5-4$, at 308-09 (2d ed. 1988) ("[W]ith its watershed decision in NLRB v. Jones and Laughlin Steel Corp., the Court acceded to political pressure and to its own recognition of its doctrine's irrelevance and manipulability...."). Treatises predating Lopez. observed that the commerce power was virtually unlimited. See, e.g., NOWAK AND ROTUNDA, supra note $27, \S 4.8$, at 154 ("The Supreme Court today interprets the commerce cause [sic] as a complete grant of power."); TRIBE, supra, §5-4, at 309 ("Since 1937 . . the Supreme Court has exercised little independent judgment, choosing instead to defer to the expressed or implied findings of Congress to the effect that regulated activities have the requisite 'substantial economic effect."”).

63. See Scarborough, 431 U.S. at 575. 
around Congress's commerce power, it is now clear that at least one of these assumptions was wrong-possession of firearms does not always affect interstate commerce. ${ }^{64}$ Now that the assumptions are open to scrutiny, treatment of Scarborough as constitutional precedent should be questioned.

Before past movement in interstate commerce is accepted as enough to meet the "substantial effect on interstate commerce" requirement, there must be a reasoned explanation of how past movement - an event wholly independent of possession-can change possession from a nonregulable activity to a regulable one. The fact is that the relationship between possession and interstate commerce is independent of the item's source; because possession of an item does not affect interstate commerce, possession of an item that moved previously in interstate commerce should not affect interstate commerce. Accordingly, the jurisdictional element should not bring regulation of possession of firearms in school zones within Congress's power over activities that substantially affect interstate commerce.

\section{B. The Alternative: Channels of Interstate Commerce or Instrumentalities of Interstate Commerce and Things in Interstate Commerce}

Although past movement in interstate commerce does not bring possession of a firearm within Congress's power over activities that substantially affect interstate commerce, one might argue that the jurisdictional element brings the act within the other two prongs of Congress's Commerce Clause power. ${ }^{65}$ Harry Litman and Mark Greenberg have made such an argument: limiting the offense to possession of a firearm that "has moved in ... interstate commerce"

64. See United States v. Lopez, 514 U.S. 549, 562 (1995) (noting the government's concession that " "[n]either the [Gun-Free School Zones Act] nor its legislative history contain[s] express congressional findings regarding the effects upon interstate commerce of gun possession in a school zone"" (quoting Brief for the United States at 5-6, United States v. Lopez, 514 U.S. 549 (1995) (No. 93-1260))). The Court's recent opinion in United States v. Morrison provides further clarification that Congress's assumptions about the extent of its power must be reexamined. United States v. Morrison, 120 S. Ct. 1740, 1748 (2000) (stating the principle-not raised in Scarborough - that Congress's power still has limits).

65. Justifying the statute under one of those powers clearly distinguishes Lopez. Lopez, 514 U.S. at 559 (noting that the original Gun-Free School Zones Act was "not a regulation of the use of the channels of interstate commerce... [or] an attempt to prohibit the interstate transportation of a commodity through the channels of commerce... [or] a regulation... [seeking] to protect an instrumentality of interstate commerce or a thing in interstate commerce"). 
brings the statute within Congress's "power to regulate things in interstate commerce [or]... Congress's power to regulate the channels of interstate commerce."

To support their argument, Litman and Greenberg rely upon Scarborough; they argue that Scarborough "necessarily, if implicitly, held that Congress has the power to regulate guns that have traveled in interstate commerce." ${ }^{67}$ Like the cases citing Scarborough discussed above, ${ }^{68}$ Litman and Greenberg argue that "[b]ecause the Court's interpretation of the statute depended on its finding that the statute had the same reach as the commerce power, the decision necessarily establishes that the commerce power reaches to the possession of any gun that has traveled in interstate commerce." ${ }^{, 69}$

This argument, however, is misplaced. As discussed above, ${ }^{70}$ Scarborough interpreted Congress's intended meaning for "or affecting commerce." " Because its focus was on affecting interstate commerce, Scarborough clearly does not support the notion that the insertion of "has moved ... in interstate ... commerce" makes the statute an exercise of Congress's power over the channels of interstate commerce or the power over things in interstate commerce.

Although Scarborough is unrelated to the channels of interstate commerce or things in interstate commerce, treatment by U.S. courts of appeals of 18 U.S.C. $\S 922(\mathrm{o})$, which criminalizes possession of machine guns, can be used to construct arguments that past movement in interstate commerce brings the firearm within those prongs of Congress's power. ${ }^{72}$ Such arguments and their frailties are addressed below.

66. Litman \& Greenberg, supra note 43 , at 930.

67. Id. at 932 (quoting Scarborough, 431 U.S. at 572).

68. See supra notes 35-40 and accompanying text.

69. Litman \& Greenberg, supra note 43, at 932-33; see also Grossman, supra note 33, at 798-99 ("If the indictment in Lopez had alleged that the firearm traveled in interstate commerce, the Court, as it had done in Scarborough, would have been free to uphold the constitutionality of the GFSZA by finding that Congress was regulating 'things in interstate commerce."'). The author's disagreement with this characterization of Scarborough's implicit holding is discussed above. See supra notes 61-64 and accompanying text.

70. See supra notes 53-59 and accompanying text.

71. The court looked only at Congress's intent " "to cover all activity substantially affecting interstate commerce." Scarborough, 431 U.S. at 571 (emphasis added) (quoting United States v. American Bldg. Maintenance Indus., 422 U.S. 271, 280 (1975)).

72. See 18 U.S.C. $\S 922(0)(1)$ (1994). The statute has also been justified as an exercise of Congress's power over activities that substantially affect interstate commerce. See, e.g., United States v. Beuckelaere, 91 F.3d 781, 785 (6th Cir. 1996) ("We find that the regulation of machinegun transfer and possession sufficiently affects interstate commerce in order to come 
1. The Channels of Interstate Commerce. Lower courts have found Congress's regulation of machine gun possession to be a constitutional exercise of the power over the channels of interstate commerce under the following theory: Congress intended to prohibit "the introduction into the stream of commerce machineguns manufactured, imported, or otherwise illegally obtained."73 Theoretically, "there could be no unlawful possession under section 922(o) without an unlawful transfer." ${ }^{\text {,74 }}$ Possession, therefore, is "a necessary and proper measure meant to allow law enforcement to detect illegal transfers where the banned commodity has come to rest: in the receiver's possession." ${ }^{75}$ Without any jurisdictional element, this justification makes the statute overbroad; while possession may require transfer, there is no justification for assuming that it requires interstate transfer. $^{76}$ Because the jurisdictional element being considered relates to interstate transfer, however, overbreadth is not a problem with regard to section $922(\mathrm{q})$.

There is no reason the same logic would not be applicable to possession of any firearm. The power to regulate the channels of interstate commerce focuses on the channels-roads, airspace, waterways, etc. - not on the goods that are moving. The goods

within Congress' power to legislate under the Commerce Clause.”) (emphasis added). Because the only difference between machine guns and other firearms is their potential danger, and because the Lopez court specifically rejected the cost of crime rationale, this justification for section $922($ o) should be reconsidered.

73. United States v. Kirk, 70 F.3d 791, 796 (5th Cir. 1995).

74. Id.

75. $I d$.

76. Perhaps, however, all possession could be reached on the theory that there cannot be transfer without possession. Because one cannot transfer a machine gun without first possessing it, regulating possession might be necessary and proper for preventing transfer. See generally Russell F. Pannier, Lopez and Federalism, 22 WM. MitCHELl L. ReV. 71, 97-98 (1996) (suggesting that Congress could avoid the limitations of Lopez via the "Darby method of legislation," whereby the statute would have two sections: (1) prohibiting interstate transport of a gun that was previously possessed by a person in a school zone, and (2) prohibiting possession in a school zone as a necessary and proper means for reducing violation of the prohibition against transport). This suggestion is problematic, however, because if possession of all items was regulable as a necessary and proper means for regulating transfer, there would be no limitation of Congress's power, and the problem Lopez tried to avoid would remain. See infra note 90 and accompanying text. While part one of the Pannier suggestion is surely within Congress's power over use of the channels of interstate commerce, part two is troublesome because it is a step removed from the ultimate power. See supra notes 86-90 and accompanying text. Nevertheless, Pannier's suggestion is more rational than the one offered in relation to section 922(o), because it includes a legitimate statute and a second provision rationally related to executing the legitimate statute's goal. 
regulated can be anything Congress pleases. ${ }^{77}$ The commodity's level of danger is not a factor. ${ }^{78}$ Thus, application of the power to regulate use of the channels of commerce is the same whether Congress is regulating machine guns or other firearms. Accordingly, the "possession to reach transfer" logic should give Congress the power to regulate possession of all firearms.

But this conclusion is curious in light of Lopez, which did not leave open the possibility that the Gun-Free School Zones Act could be constitutional as a regulation of the channels of interstate commerce. The doctrine was so well settled that the Court simply announced that " $\$ 922(\mathrm{q})$ [was] not a regulation of the use of the channels of interstate commerce."

Perhaps the version of section 922(q) repudiated in Lopez was distinguishable from section 922 (o) because, as a necessary and proper measure to regulate transfer of firearms, it would have been underbroad; if Congress intended to regulate transfer by regulating possession, it would have regulated all possession, not just possession in a school zone. However, such a distinction would lead to the illogical conclusion that Congress can regulate possession of all firearms but cannot regulate possession of firearms in a specific place. ${ }^{80}$ To avoid such a conclusion, the scope of Congress's power over the channels of interstate commerce should be examined.

77. See Regan, supra note 22 , at 560 (noting that the "goods" regulated can even be people).

78. See Kirk, 70 F.3d at 799 (Jones, J., dissenting) (noting that the commerce power is not a function of the item's level of danger and reflecting that "[o]bviously, eggs as well as toxic chemicals can be regulated if they have the appropriate nexus to interstate commerce"); Regan, supra note 22, at 560 .

79. United States v. Lopez, 514 U.S. 549, 559 (1995). If possession of a firearm in a school zone is not a use of the channels of interstate commerce, how can it be that the same act of possession becomes a use of the channels of interstate commerce just because the firearm moved in interstate commerce years before?

80. In an analogous situation, however, courts have upheld the Drug-Free School Zones Act even though "trafficking in controlled substances near schools does not affect interstate commerce any more than trafficking elsewhere." United States v. McKinney, 98 F.3d 974, 977 (7th Cir. 1996). Such regulation is distinguishable, however, from regulation of possession of a firearm in a school zone because "a key element of the crime-drug trafficking—clearly 'substantially affects interstate commerce." United States v. Tucker, 90 F.3d 1135, 1140 (6th Cir. 1996). In addition, although the penalty is more severe for drug trafficking in a school zone, drug trafficking itself is prohibited without regard to location. See 21 U.S.C. § 841(a)(1) (1994) (making it unlawful "to manufacture, distribute, or dispense, or possess with intent to manufacture, distribute, or dispense, a controlled substance"); id. § 860(a) (describing an increased penalty for drug trafficking in a school zone). 
The channels of interstate commerce are roads, waterways, airspace, and other loci for moving goods from one state to the next. ${ }^{81}$ Congress's broad power to regulate how the channels of interstate commerce are used is based on the Constitution's Necessary and Proper Clause. ${ }^{82}$ Because interstate commerce relies on the channels for moving goods across state lines, regulation of the way the channels are used is "necessary and proper" for the execution of the enumerated power. To facilitate execution of its power over interstate commerce, Congress has broad authority to keep these channels "free from immoral and injurious uses. ${ }^{, 83}$ This power allows Congress to "prohibit the movement across state lines of anything it pleases." For example, Congress can regulate the shipment of stolen goods or of kidnapped persons. ${ }^{85}$

Although Congress's power over the channels of interstate commerce is so broad that Congress's motive need not even be related to commerce, ${ }^{86}$ the power is not unlimited. Its scope is restricted to regulating use of the channels to perform certain tasks

81. See Perez v. United States, 402 U.S. 146, 150 (1971).

82. U.S. CONST. art. I, $\S 8$, cl. 18 (empowering Congress "[t]o make all Laws which shall be necessary and proper for carrying into Execution" its enumerated powers).

83. Caminetti v. United States, 242 U.S. 470, 491 (1917); see also North Am. Co. v. Securities \& Exch. Comm'n, 327 U.S. 686, 705 (1946) (reiterating “the well-settled principle that Congress may impose relevant conditions and requirements on those who use the channels of interstate commerce in order that those channels will not become the means of promoting or spreading evil, whether of a physical, moral or economic nature") (citing Brooks v. United States, 267 U.S. 432, 436-37 (1925)).

84. Regan, supra note 22, at 560; cf., e.g., United States v. Orito, 413 U.S. 139, 144 (1973) (upholding the prohibition against transporting obscene materials in interstate commerce); United States v. Darby, 312 U.S. 100, 112 (1941) (holding that, while Congress may not have the authority to impose labor standards on the manufacture of lumber, the prohibition against shipping in interstate commerce lumber produced with child labor was a legitimate regulation of interstate commerce); Brooks v. United States, 267 U.S. 432, 438-39 (1925) (holding that Congress had authority to prohibit the transport of stolen motor vehicles in interstate commerce because such conduct is a "gross misuse of [the channels of] interstate commerce"); Caminetti, 242 U.S. at 491 (upholding Congress's power to regulate " $\mathrm{t}$ ] he transportation of passengers [in this case, prostitutes] in interstate commerce" under its authority "to keep the channels of interstate commerce free from immoral and injurious uses").

85. See Perez, 402 U.S. at 150.

86. See, e.g., Darby, 312 U.S. at 115-16 (upholding Congress's attempt to restrict child labor by prohibiting use of the channels of interstate commerce to transport goods produced via child labor). Other examples of Congress's use of its power over the channels of interstate commerce to achieve goals unrelated to commerce include restricting theft by prohibiting the use of the channels of interstate commerce to ship stolen goods, and restricting kidnapping by prohibiting the use of the channels of interstate commerce to ship persons who have been kidnapped. See Perez, 402 U.S. at 150 (citing 18 U.S.C. $\S \S 2312-15$ (regulating shipment of stolen goods); 18 U.S.C. $\$ 1201$ (regulating shipment of kidnapped persons)). 
and use of the channels after performing certain tasks; the focus is on regulating how the channels are used. ${ }^{87}$ Peripheral activities not involving transport are excluded. An action that is not itself a use of the channels of interstate commerce-here, possession of a guncannot become regulable simply because it is necessary and proper to execute the power over use of the channels of interstate commerce. It must be necessary and proper for execution of the power to regulate interstate commerce.

Congress does not have the power to bootstrap new powers onto powers that are necessary and proper for the execution of enumerated powers unless the new power is also necessary and proper for the execution of the enumerated power. For Congress's power to arise, four conditions must be met: (1) the regulation must be plainly adapted to a constitutional end; (2) the regulation may not be otherwise prohibited by the Constitution; (3) the regulation must be "appropriate"; and (4) the regulation "must be consistent with both the letter and the spirit of the Constitution." 88 To uphold a regulation as necessary and proper to execute the power over use of the channels of interstate commerce would violate the first and fourth requirements.

87. See Darby, 312 U.S. at 115-16 (holding that Congress could prohibit transport in interstate commerce of goods produced through child labor because Congress's power is plenary, regardless of motive and purpose); see also Perez, 402 U.S. at 150 (summarizing the power over the channels of interstate commerce as a power over the "use of channels ... which Congress deems are being misused").

88. Stephen Gardbaum, Rethinking Constitutional Federalism, 74 TEX. L. REV. 795, 815-16 (1996) (breaking down Chief Justice Marshall's famous proclamation in M'Culloch v. Maryland, 17 U.S. 316, 421 (1819): "Let the end be legitimate, let it be within the scope of the Constitution, and all means which are appropriate, which are plainly adapted to that end which are not prohibited, but consist with the letter and spirit of the Constitution, are constitutional") (emphasis added); see also David M. Burke, The "Presumption of Constitutionality" Doctrine and the Rehnquist Court: A Lethal Combination for Individual Liberty, 18 HARV. J.L. \& PUB. POL'Y 73, 160 (1994) (concluding that a measure that "does not directly advance or promote a legitimate interest identified by Congress" should be invalidated) (emphasis added); David E. Engdahl, Intrinsic Limits of Congress' Power Regarding the Judicial Branch, 1999 BYU L. REV. 75,101 (asserting that Congress's broad power under the Necessary and Proper Clause is limited to executing the Constitution's design, as opposed to altering it); David G. Wille, The Commerce Clause: A Time for Reevaluation, 70 TUL. L. REv. 1069, 1084 (1996) (asserting that "[a]n 'end' refers to one of the enumerated powers of Congress in Article I" and "[a] 'means' is simply a particular power used to exercise a more general enumerated power, or a tool used in exercising an enumerated power"). Although reliance on a case as old as $M^{\prime}$ 'Culloch is unusual, Gardbaum asserts that "it is because M'Culloch is not simply $a$ case but is effectively the only case interpreting the Necessary and Proper Clause that the emphasis placed on it here is justified." Gardbaum, supra, at 814. 
First, the power over the use of the channels of interstate commerce is not a constitutional end. Accordingly, it is not enough that the assertion of power is necessary and proper for the execution of the power over the channels of interstate commerce. Second, allowing Congress to bootstrap new powers onto powers necessary and proper for the execution of enumerated powers would be inconsistent with the letter and spirit of the Constitution-the interest in federalism would be eradicated. ${ }^{89}$ Part of the rationale in Lopez was that creative reasoning should not be used to enable Congress to reach virtually any activity. ${ }^{90}$ If Congress could create powers necessary and proper to execute powers necessary and proper to execute enumerated powers, eventually Congress would avoid the Lopez reasoning to reach virtually any activity. To the extent that Congress rationally could have believed that regulating possession was necessary and proper for regulating interstate commerce, the justification would either create a new category or be an assertion that possession substantially affects interstate commerce. ${ }^{91}$

Thus, regulation of possession cannot be justified as necessary and proper for executing the power over use of the channels of interstate commerce. The jurisdictional element does not bring

89. See Gardbaum, supra note 88, at 816 ("Marshall did not mean some free-floating, textually disembodied, open-ended and indeterminate metanorm, but was rather referring to certain specific and widely acknowledged background principles-such as federalism and the separation of powers-which even if not specifically incorporated into the text of the Constitution, nonetheless inform its interpretation.").

90. See United States v. Lopez, 514 U.S. 549, 564 (1995) (asserting that "cost of crime" reasoning and "national productivity" reasoning could not be accepted because such reasoning would make it "difficult to perceive any limitation of federal power, even in areas such as criminal law enforcement or education where States historically have been sovereign"); Transcript of Oral Argument, Lopez (No. 93-1260), 1994 WL 758950, at *5 (Nov. 8, 1994) ("QUESTION [by Justice O'Connor]: If [possession of a gun in a school zone] is covered, what's left of enumerated powers? What is there that Congress could not do, under this rubric ...?"); see also Burke, supra note 88, at 110 (noting that the Necessary and Proper Clause restates a power that inevitably would have been implied); Thomas B. McAffee, The Federal System as Bill of Rights: Original Understandings, Modern Misreadings, 43 VILL. L. REV. 17, 4647 (1998) (reflecting on the Federalists' position that the Necessary and Proper Clause "was purely declaratory in nature and that it merely set forth the principle of agency that would have followed naturally, with or without such an explicit text, from the necessity of ancillary authority in a system of limited grants of power"); Wille, supra note 88, at 1083 ("If, in the absence of [the Necessary and Proper Clause], Congress would have the same scope of power by implication as it does with the presence of the Clause, the Necessary and Proper Clause cannot expand those powers otherwise enumerated."). This rationale was revisited in United States v. Morrison, 120 S. Ct. 1740 (2000). See infra note 121.

91. Of course, this brings the analysis back to determining when an activity substantially affects interstate commerce. See supra notes 21-64 and accompanying text. 
section 922(q) within Congress's power over use of the channels of interstate commerce. ${ }^{92}$

2. Instrumentalities of Interstate Commerce and Things in Interstate Commerce. Lower courts have found Congress's regulation of machine gun possession to be a constitutional exercise of the power over instrumentalities of interstate commerce and things in interstate commerce under the following theory: machine guns are " "a commodity... transferred across state lines for profit by business entities" "and are, therefore, per se regulable. ${ }^{93}$ To reach this conclusion, courts have compared machine guns to narcotics and other products that Congress regulates. ${ }^{94}$ Because machine guns are transferred across state lines for profit as commerce, they are regulable as are any other things in interstate commerce. ${ }^{95}$ Although regulating possession of all machine guns may be overbroad on the ground that there is no guarantee that all machine guns are in interstate commerce, limitation to machine guns that have in the past moved in interstate commerce would provide the individualized link required by Lopez.

There is no reason this logic would not apply to possession of ordinary firearms. The power over things in interstate commerce is not a function of dangerousness. If machine guns are regulable as items in commerce, so are other firearms. ${ }^{96}$ If firearms are items in interstate commerce, over which Congress has plenary power, Congress would have the power to regulate possession of firearms in

92. The power only allows Congress to prohibit transfer after the firearm has been possessed within a school zone. See Pannier, supra note 76, at 97-98. Such a prohibition, however, would not be very practical. By the time the gun is transferred out of the school zone, it may be too late.

93. United States v. Wilks, 58 F.3d 1518, 1521 (10th Cir. 1995) (quoting United States v. Hunter, 843 F. Supp. 235, 249 (E.D. Mich. 1994)).

94. See id. (citing United States v. Atkinson, 513 F.2d 38, 39-40 (4th Cir. 1975) (allowing Congress to regulate possession of narcotics); United States v. Evans, 712 F. Supp. 1435, 1442 (D. Mont. 1989) (upholding the regulation of interstate transportation of products, including firearms).

95. See Wilks, 58 F.3d at 1521; United States v. Beuckelaere, 91 F.3d 781, 786 (6th Cir. 1996) ("[M]achineguns... by their very nature are a commodity that move in interstate commerce.").

96. Theoretically, if all items that ever moved in interstate commerce were regulable as things in interstate commerce, Congress would have limitless power to regulate possession. For example, Congress would be able to regulate possession of alcohol. The federal government would have the power to impose a mandatory minimum sentence on a high school valedictorian caught holding an open container for the first time during fraternity rush! 
a school zone. This logic, however, once again fails to distinguish Lopez. ${ }^{97}$

Examining Congress's power over things in interstate commerce explains why Lopez does not discuss whether section 922(q) was a regulation of things in interstate commerce. The power to regulate things in interstate commerce is not a broad power to regulate all commodities that ever moved across state lines. Although the power reaches intrastate activities, it covers only "the instrumentalities of interstate commerce, or persons or things in interstate commerce."

Like the power over the channels of interstate commerce, the power over the instrumentalities of interstate commerce and things in interstate commerce is a necessary and proper derivative of Congress's power over interstate commerce. ${ }^{99}$ The rationale is that "interstate and intrastate transactions are interwoven." Congress needs power over intrastate vehicles to assure that regulation over interstate vehicles will be effective. ${ }^{101}$ For example, regulating intrastate vehicles may be necessary to assure that safety goals for interstate traffic will be achieved. ${ }^{102}$ Similarly, in order to regulate interstate commerce effectively, it is necessary to regulate goods while they are in commerce. Based on the relationship between instrumentalities of interstate commerce and things in interstate commerce, Congress's power over instrumentalities of interstate commerce and things in interstate commerce is as follows.

"Instrumentalities of interstate commerce" are vehicles or other facilities, such as warehouses or depots, used for moving goods in interstate commerce. ${ }^{103}$ For example, a stockyard is considered an

97. See United States v. Lopez, 514 U.S. 549, 559 (1995) (“[N]or can § 922(q) be justified as a regulation by which Congress has sought to protect an instrumentality of interstate commerce or a thing in interstate commerce."). Indeed, the addition of the jurisdictional element has almost no effect on the "things in interstate commerce" logic.

98. Id. at 558 .

99. See Houston, E. \& W. Tex. Ry. Co. v. United States, 234 U.S. 342, 353 (1914) (authorizing Congress to "take all measures necessary or appropriate" to the exercise of its "paramount power" over interstate commerce); Southern Ry. Co. v. United States, 222 U.S. 20, 26-27 (1911) (justifying regulation of vehicles used for intrastate traffic on the basis that the goals of achieving safety for vehicles used for interstate travel would be promoted by regulating vehicles used for intrastate travel).

100. United States v. New York Cent. R.R. Co., 272 U.S. 457, 464 (1926).

101. See id.

102. See Southern Ry. Co., 222 U.S. at 26.

103. See, e.g., Perez v. United States, 402 U.S. 146, 150 (1971) (suggesting that the power over the instrumentalities of interstate commerce authorizes Congress to prohibit "the destruction of an aircraft"); Houston, E. \& W. Tex. Ry. Co., 234 U.S. at 352-53 (allowing 
instrumentality of interstate commerce because it is a "throat through which [interstate commerce] flows, and the transactions which occur therein are only incident" to the movement of goods in interstate commerce. $^{104}$ Under this definition, a firearm clearly is not an instrumentality of interstate commerce.

"Things in interstate commerce" are items stored in an instrumentality of interstate commerce or specifically set aside as interstate commerce. ${ }^{105}$ Such items are regulable only while they are in the flow of interstate commerce. ${ }^{106}$ Once a good comes to rest in a state, the flow in interstate commerce comes to an end. ${ }^{107}$ Thus, while an item stored temporarily in a warehouse with the intention of being shipped to another state is regulable as an item in interstate commerce, an item resting in a retail outlet for resale to a local customer is not a "thing in interstate commerce." fact that a firearm previously moved in interstate commerce is not enough to make the firearm a regulable "thing in interstate commerce."

Furthermore, the comparison to narcotics and other products that Congress has the power to regulate does not support the conclusion that section 922(o) is justified as regulation of a thing in interstate commerce. While congressional regulations of many products have survived constitutional challenges, the justification has not been that all products are things in interstate commerce. Rather,

Congress to regulate carriers of intrastate traffic because such regulation was necessary in order to facilitate regulation of carriers of interstate traffic); Southern Ry. Co., 222 U.S. at 25 (upholding federal safety requirements for railroad cars without requiring a limitation to the cars actually moving in interstate commerce).

104. Stafford v. Wallace, 258 U.S. 495, 516 (1922).

105. See United States v. Gollin, 176 F.2d 889, $893-94$ (3d Cir. 1949) (upholding a federal prohibition of theft from interstate shipments where the defendant had stolen goods that were stored in a truck and set aside for shipment in interstate commerce).

106. See A.L.A. Schechter Poultry Corp. v. United States, 295 U.S. 495, 543 (1935).

107. See id.

108. See id. This distinction also helps explain why drug trafficking is justified under the substantial effects prong rather than regulation of things in interstate commerce. Even if drug trafficking could be reached under the power over things in interstate commerce (on a theory that the flow continues until the final purchase), it would not reach possession without intent to distribute. Similarly, while possession of a firearm alone does not fall within Congress's power over things in interstate commerce, perhaps a more successful argument could be made to reach possession with intent to distribute. Of course, to be successful, such an argument would require extension of the power over things in interstate commerce. 
the power has been justified as regulation of items substantially affecting interstate commerce. ${ }^{109}$

Thus, the jurisdictional element does not make section 922(q) a constitutional exercise of Congress's power over the channels of interstate commerce and things in interstate commerce. Accordingly, past movement in interstate commerce does not automatically give Congress the power to regulate possession. The final change to the Gun-Free School Zones Act that must be considered is the addition of Congress's findings to the face of the statute.

\section{FINDINGS}

In addition to the jurisdictional element, the revisions to 18 U.S.C. $§ 922(\mathrm{q})$ include congressional findings regarding the relationship between possession of firearms in a school zone and interstate commerce. ${ }^{110}$ The decision to include findings likely resulted from Chief Justice Rehnquist's comments in Lopez that, although findings are not normally required, "to the extent that congressional findings would enable us to evaluate the legislative judgment that the

109. See, e.g., United States v. Crump, 120 F.3d 462, 465 (4th Cir. 1997) (““Trafficking,' of course, not only substantially affects commerce; it is commerce."); United States v. Orozco, 98 F.3d 105, 107 (3d Cir. 1996) ("Drug trafficking is an inherently commercial activity; the mere possession of a firearm is not. Drug trafficking near a school zone is an economic activity that, through repetition, substantially affects interstate commerce."); United States v. Tucker, 90 F.3d 1135, 1140 (6th Cir. 1996) ("[D]rug trafficking is an 'economic enterprise' that substantially affects interstate commerce in numerous clear ways. Each individual instance of cocaine dealing, for example, represents the end point of a manufacturing, shipping, and distribution network that is interstate-and international-in nature.") (emphasis added); United States v. Staples, 85 F.3d 461, 463 (9th Cir. 1996) ("[D]rug trafficking is a commercial activity which substantially affects interstate commerce.”).

Furthermore, cases since Lopez analyzing Congress's regulation of drugs note the distinction between mere possession and possession related to interstate commerce through intent to distribute or the act of trafficking. See, e.g., Orozco, 98 F.3d at 107 ("The Gun-Free School Zones Act and the Drug-Free School Zones Act are distinguishable. [The Gun-Free School Zones Act] punished mere possession of a firearm near a school. In contrast, [the DrugFree School Zones Act] prohibits the sale, distribution and possession with intent to distribute illegal drugs near a school.").

110. See 18 U.S.C. § 922(q)(1) (Supp. IV 1998); see also supra note 11 (listing the findings). The findings were originally added before the Supreme Court issued its opinion in Lopez. However, because they were not added until after Mr. Lopez was prosecuted, the Lopez Court did not treat the findings as part of the statute's text. See 18 U.S.C. § 922(q)(1) (1994); United States v. Lopez, 514 U.S. 549, 617-18 (1995) (Breyer, J., dissenting); id. at 562 ("[T]he government concedes that '[n]either the statute nor its legislative history contain[s] express congressional findings regarding the effects upon interstate commerce of gun possession in a school zone." (quoting Brief for the United States at 5-6, United States v. Lopez, 514 U.S. 549 (1995) (No. 93-1260))). 
activity in question substantially affected interstate commerce, even though no such substantial effect was visible to the naked eye, they are lacking here." 111 The addition of findings in this case, however, does nothing to make the statute survive the reasoning in Lopez.

Before proscribing possession of firearms that have moved in interstate commerce in school zones, Congress found that "crime ... is a pervasive, nationwide problem."112 This nationwide problem is "exacerbated by the interstate movement of drugs, guns, and criminal gangs." ${ }^{113}$ Fear of guns may lead to citizens and foreign visitors being afraid to travel. ${ }^{114}$ The same concern may also lead to parents "declin[ing] to send their children to school." crime in school zones has resulted in a decline in the quality of education in our country." 116 This decline in education adversely affects interstate commerce. ${ }^{117}$ Accordingly, "Congress [asserted] the power, under the interstate commerce clause" to regulate possession of firearm in school zones. ${ }^{118}$

By asserting that guns in school zones lead to a decline in education and therefore adversely affect interstate commerce, the findings codify the "cost of crime" reasoning that was specifically rejected in Lopez. ${ }^{119}$ The Court's recent opinion in United States v. Morrison $^{120}$ confirms that adding congressional findings with nothing more to the face of the statute should have no effect. ${ }^{121}$ In Morrison, the Court repudiated part of the Violence Against Women Act ${ }^{122}$ even though it was "supported by numerous findings regarding the

\footnotetext{
111. Lopez, 514 U.S. at 563.

112. 18 U.S.C. $\$ 922(q)(1)(A)$ (Supp. IV 1998).

113. Id. $\S 922(\mathrm{q})(1)(\mathrm{B})$.

114. See id. $\S 922(\mathrm{q})(1)(\mathrm{E})$.

115. Id.

116. $I d . \S 922(\mathrm{q})(1)(\mathrm{F})$.

117. See id. $\S 922(\mathrm{q})(1)(\mathrm{G})$.

118. Id. $\S 922(\mathrm{q})(1)(\mathrm{I})$.

119. United States v. Lopez, 514 U.S. 549, 564 (1995) (rejecting “cost of crime" reasoning).

120. 120 S. Ct. 1740 (2000).

121. The Court reasserted that "cost of crime" reasoning would unacceptably give Congress unlimited power. See id. at 1752-53:

If accepted, petitioners' reasoning would allow Congress to regulate any crime as long as the nationwide, aggregated impact of that crime has substantial effects on employment, production, transit, or consumption. Indeed, if Congress may regulate gender-motivated violence, it would be able to regulate murder or any other type of violence since gender-motivated violence, as a subset of all violent crime, is certain to have lesser economic impacts than the larger class of which it is a part.

122. 42 U.S.C. $§ 13,981$ (1994).
} 
serious impact that gender-motivated violence has on victims and their families." ${ }^{123}$ The Court held that "the existence of congressional findings is not sufficient, by itself, to sustain the constitutionality of Commerce Clause legislation." 124 Where the findings rely on reasoning that the Court has already rejected, they are insufficient to make the statute constitutional. ${ }^{125}$ Because the Court rejected the findings in Lopez, the fact that they are now on the face of the statute does not bring the statute within Congress's Commerce Clause power.

Nevertheless, appropriate findings could one day make the statute constitutional. The "cost of crime" findings were rejected by Lopez because of fear that the same reasoning could be used to reach any activities potentially related to violent crime. ${ }^{126}$ This logic, however, should not rule out the possibility that Congress could commission a legitimate study that reaches conclusions specifically demonstrating the effect that possession of firearms in school zones has on interstate commerce. If such findings distinguished possession of guns in school zones from other activities relating to violent crime, it would be possible for Congress to enact legislation tailored to eradicate the adverse effects on interstate commerce. Because the risk of giving Congress jurisdiction over all criminal activity would be avoided, such legislation conceivably could be constitutional. ${ }^{127}$ However, until it has specific findings, Congress will not be able to assert its power through the formality of "finding" an effect on interstate commerce.

\section{CONCLUSION}

The addition of a jurisdictional element and findings to the GunFree School Zones Act addresses the problems raised in Lopez. Limiting the offense to possession "affecting interstate or foreign commerce" at least makes the statute constitutional on its face. However, doubt remains as to whether the jurisdictional element

123. Morrison, 120 S. Ct. at 1752.

124. Id. at 1752 .

125. See id. at 1752-53.

126. United States v. Lopez, 514 U.S. 549, 564 (1995).

127. Ultimately, however, only the Court can determine whether the findings demonstrate a sufficient effect on interstate commerce to come under Congress's commerce power. See Morrison, 120 S. Ct. at 1752 ("Whether particular operations affect interstate commerce sufficiently to come under the constitutional power of Congress to regulate them . . . can be settled finally only by [the Supreme] Court.”). 
makes the statute constitutional when the only connection to interstate commerce is that the firearm has moved in interstate commerce. Until Congress offers a reasoned explanation of how past movement in interstate commerce makes subsequent possession affect interstate commerce, the constitutionality of a federal crime prohibiting possession in a school zone of a gun that has moved in interstate commerce, with nothing more, remains in grave doubt. 